\title{
Zinc Finger Protein SNAI1
}

National Cancer Institute

\section{Source}

National Cancer Institute. Zinc Finger Protein SNA11. NCI Thesaurus. Code C91262.

Zinc finger protein SNAI1 (264 aa, $29 \mathrm{kDa}$ ) is encoded by the human SNAl1 gene. This protein plays a role in both transcription and gastrulation. 